Utah State University

DigitalCommons@USU

1979

\title{
Seasonal variation in soil nutrients under six rocky mountain vegetation types
}

T. Weaver

F. Forcella

Follow this and additional works at: https://digitalcommons.usu.edu/aspen_bib

Part of the Forest Sciences Commons

\section{Recommended Citation}

Weaver, T. and Forcella, F., "Seasonal variation in soil nutrients under six rocky mountain vegetation types" (1979). Aspen Bibliography. Paper 4588.

https://digitalcommons.usu.edu/aspen_bib/4588

This Article is brought to you for free and open access by the Aspen Research at DigitalCommons@USU. It has been accepted for inclusion in Aspen Bibliography by an authorized administrator of DigitalCommons@USU. For more information, please contact

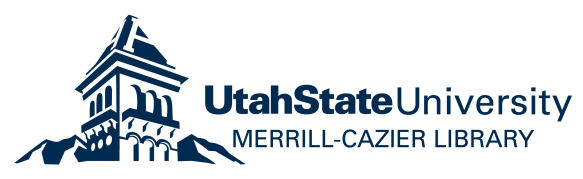




\title{
DIVISION S-7-ROREST AND RANGE SOLLS
}

\author{
Scasonal Varation in Soll Nuricuts Under Six Rocky Mommain Vegetation Types
}

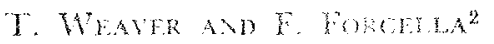

\begin{abstract}
A $\mathrm{XSI}$ I

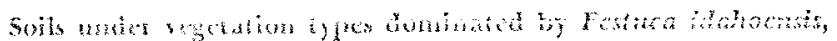

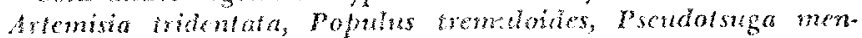

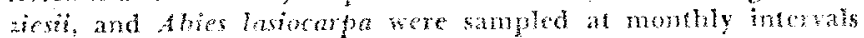
furing 197 and 1975 so detemine the magnitute of semonal vatiaton in mutrent avalisbilty. Resules may be stmmatized by expresing minimal values oberved in 1974 as a prescontage

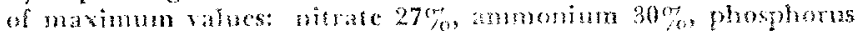

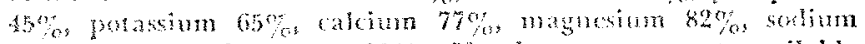

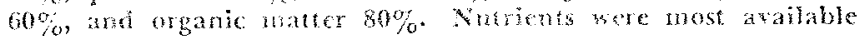

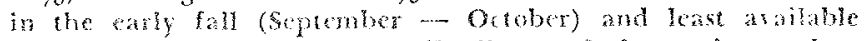

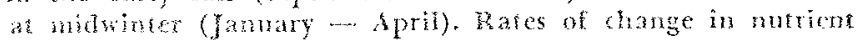

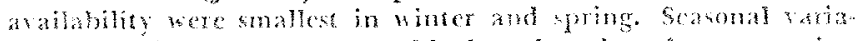

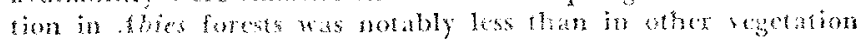
types.
\end{abstract}

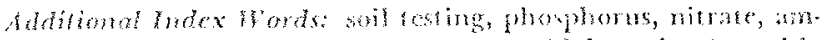

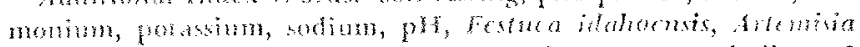

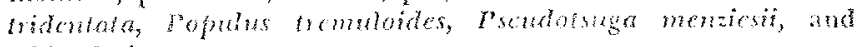
Alies lasion mpr.

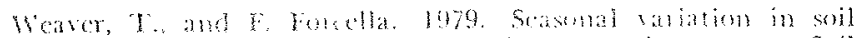

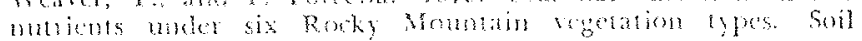
si. Soc. Am. J. 49599893.

I

F solk ms are to be used in making managenent - dersions, those gualities whin wry wh season must be reognied and smplod rither periodically or at a stantard time (Ban and Whliams, 1968; Thake more 1966; Gabouthes, 1966 ; Antoron and Ticdeman, 1970). The stuly perented helow shows that

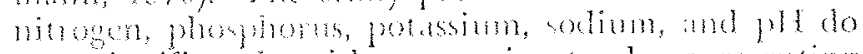

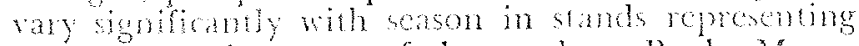
major resention ypes of the nomben Rocky Wonn.

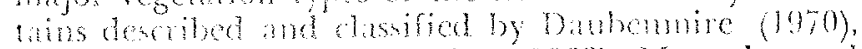

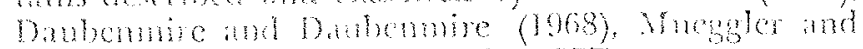

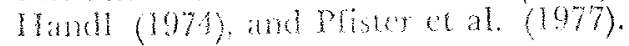

\section{VeThONS}

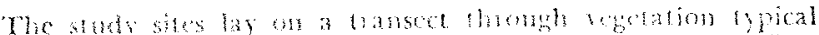

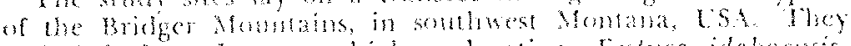

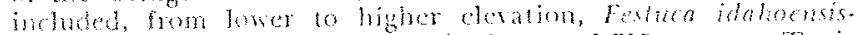
Agropyon stratum.lua prefersis site et 1.715 m on a Typic

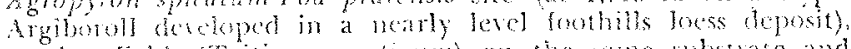

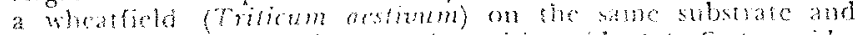

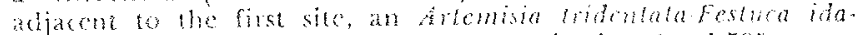

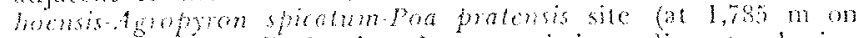

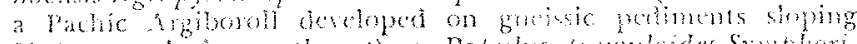

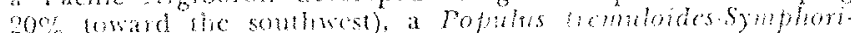

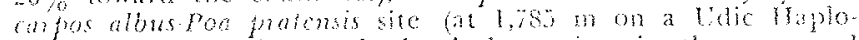

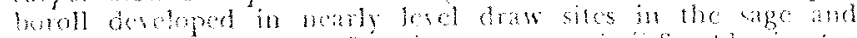

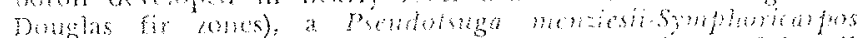

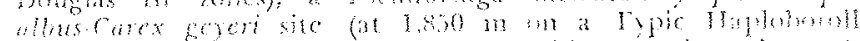

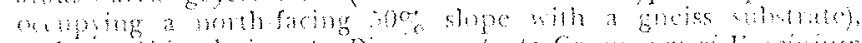

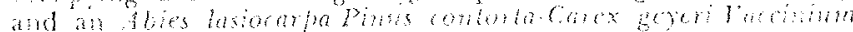

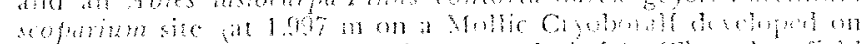

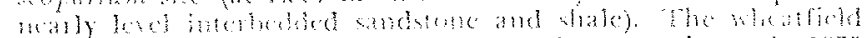

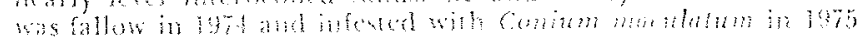

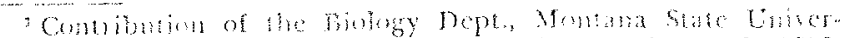

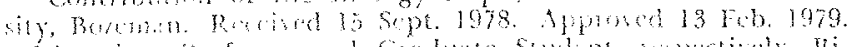

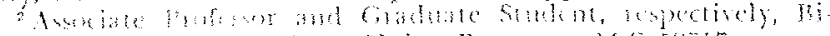

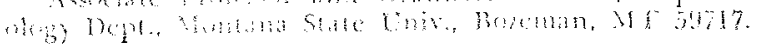

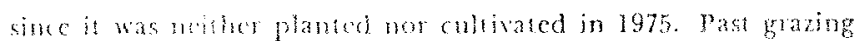

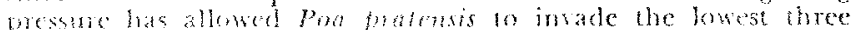

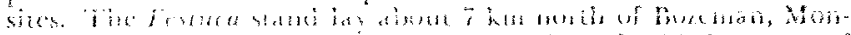
tana; the Pserdorseg stand lay appoximately $2.5 \mathrm{~km}$ east of

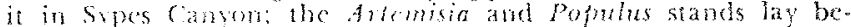

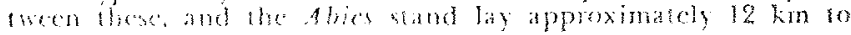

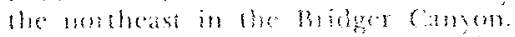

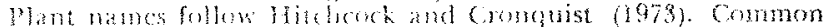

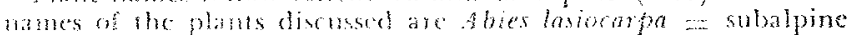

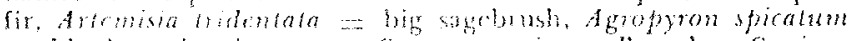

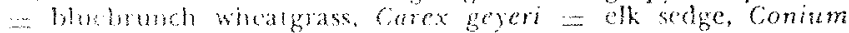
mantulum -.. poison homkak. Festuca idnhoensts = idaho fes-

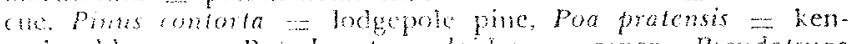

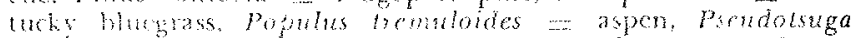

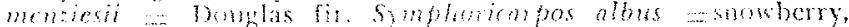

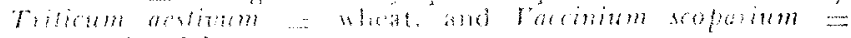

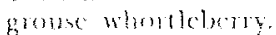

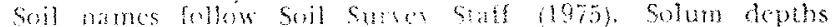

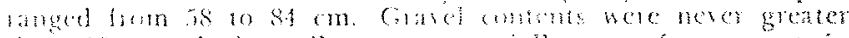

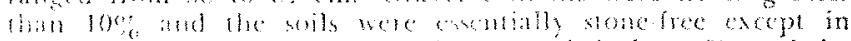

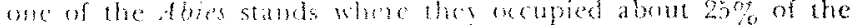

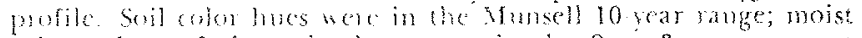

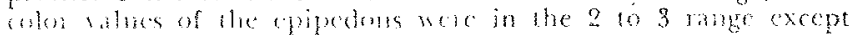

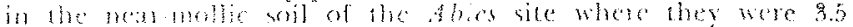

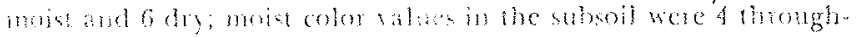
(int.

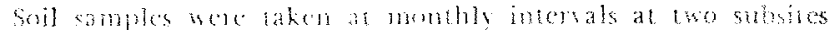
repesentative of reble site the subeites were separated by $>$ $30 \mathrm{~m}$ and $<400 \mathrm{~m}$. The sample aten at ach stobite con-

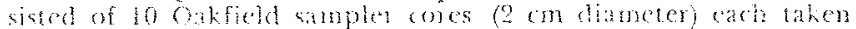

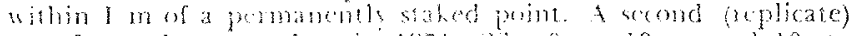
set of samples was taken in 147 , the $0.4010 \mathrm{~cm}$ and $10-40$

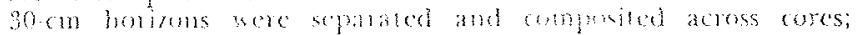

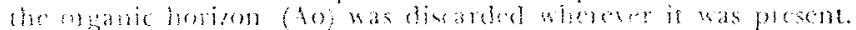
The 0 to $10 \mathrm{~cm}$ holizom ane from the 11 homison in all

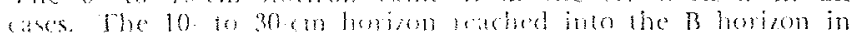

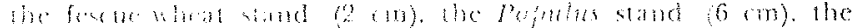

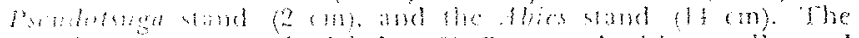

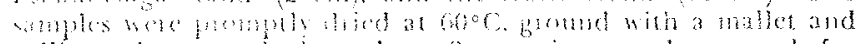

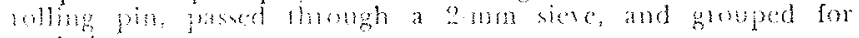
amlisis.

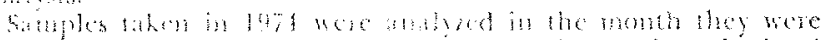

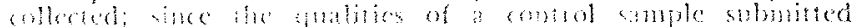

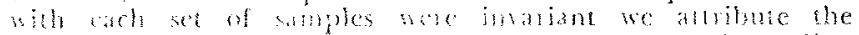

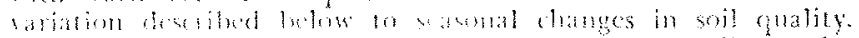

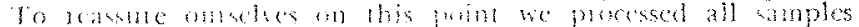

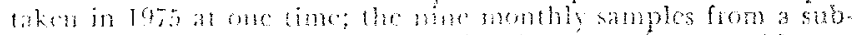

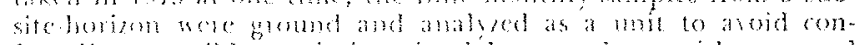

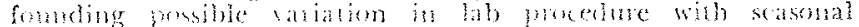

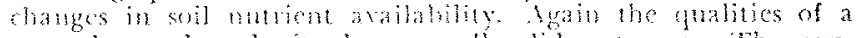

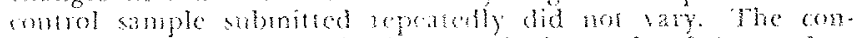

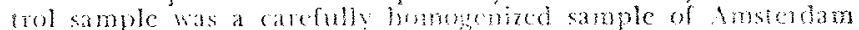
sile loan smonitfed as a hab standard with ach mu.

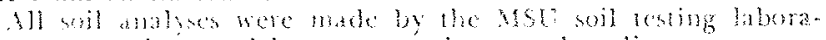

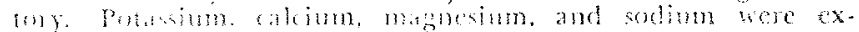

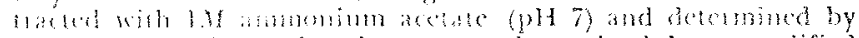

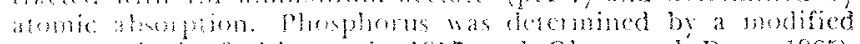

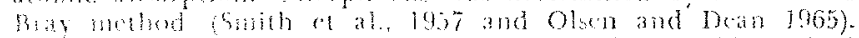

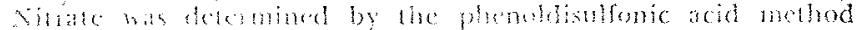

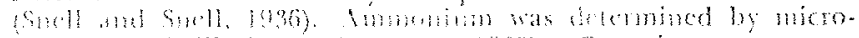

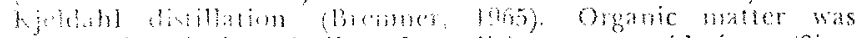

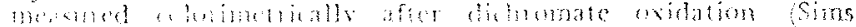

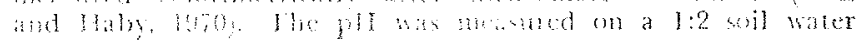
foste.

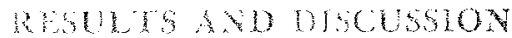

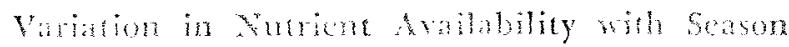

Fouses 1 and 2 illustrate the seasonal rabuton in

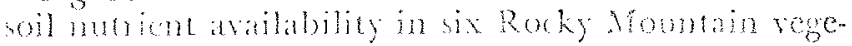




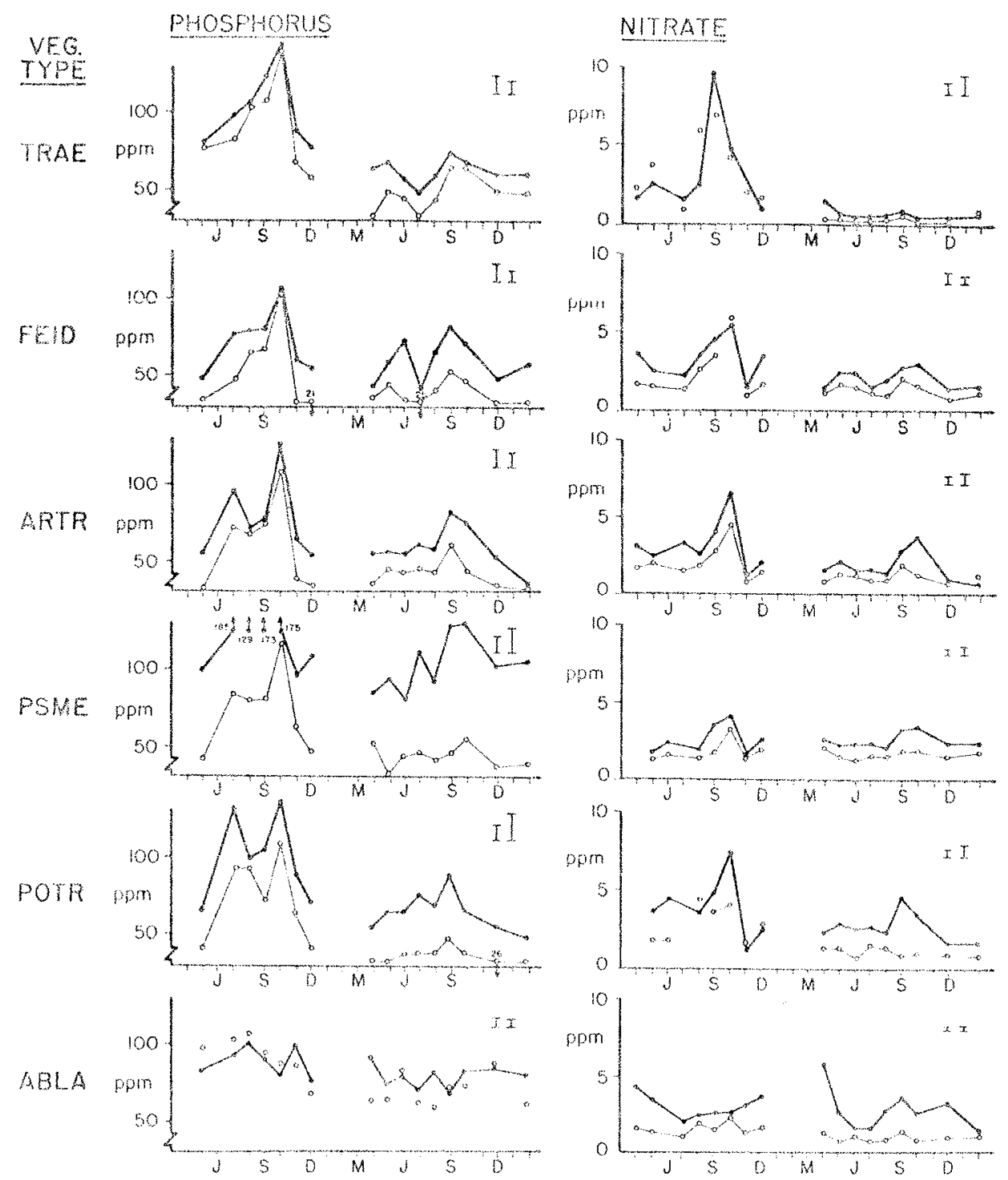

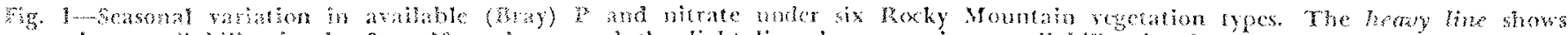

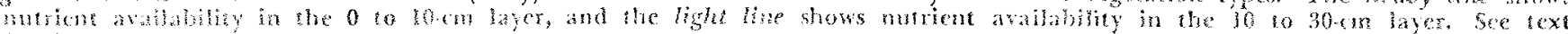
for funter splantion.

thion tyes. The vegetaion ypes and thet abbrestalons are Tritiom aestivum (TRAE), Festuca idahoensis (FED). Artemista tridentata (ARTA), Psendotsuga menteri (PSNE), Populus tromuloides (POTR) and Ables lasionpa (ABI.A). Average standard exrors astociared with the points presented are indiared by a pair of rentical bars at the top of each gen in fre 1 and 2 : the lef bars indicate the averagz 0 - $10 \mathrm{~cm}$ studard oror and he right bat indicates the areage $10.30 \mathrm{~cm}$ standare erros.

bhosphorus, nitrate and ammonim sary logether wh seson (Fig. 1, 2). In both 197 and 1975 peaks in the andability of phosplate, nitume and ammonium apene in enty fall (Sertort.) in stands of wheat, Atwmisin, Psendolsuga, and Populus. A luset peak nupens in the spring of 1974 ; it is bost illustrated by the july phosphorus data from the restuca gassland, the Artomisia shrubland, and the fromotsuga and Pophas forests. A spring peak is also smbgested by 197 nimate data from the what fichd, Prodotsuga fuest, and populus forest. The spring pedk did not appear in 1975 pentaps becane air temperatmes were
$20 \mathrm{C}$ bolow nomal in February, April, and May of 1975 whle there were $2^{\circ} \mathrm{C}$ above nomal in April, June, and July of 1974 .

The pll tropped in Onober 1974 at the same time that phosphorus, nitute and ammonium were rising.

Polabium anabibility peaked I month eatier (Sept. 1974) in stands of wheat, Festuca, Artemisia, and Pseu

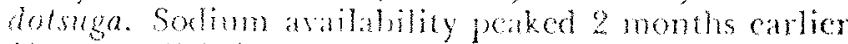
(Amgust 197) in all regetation syes studed.

thalable calcim, magnesim, and organic mater vared Iule and showed no somsonal vends either wh. in or between vegetation ypes. Cocfficients of varia. fion (statudarl deviation/mean) arross seven months of 1974 arelage 9 t $5 \%$ for calcim, $9+6 \%$ for magmeime and $11+5 \%$ for orgunic matter.

Significant changes in numbent avalability with sason have been shown in oher vegetation types. In Pritish fields nitrate, phosphorus, and potassium all become more avalable in the fall (Russell, 1061; Bhakomore, 1965; Garbouchev, 1965). British Deschampsia grasshats show spring peaks in anmonium and phosphorus and a fall peak in nivate (Davey and 


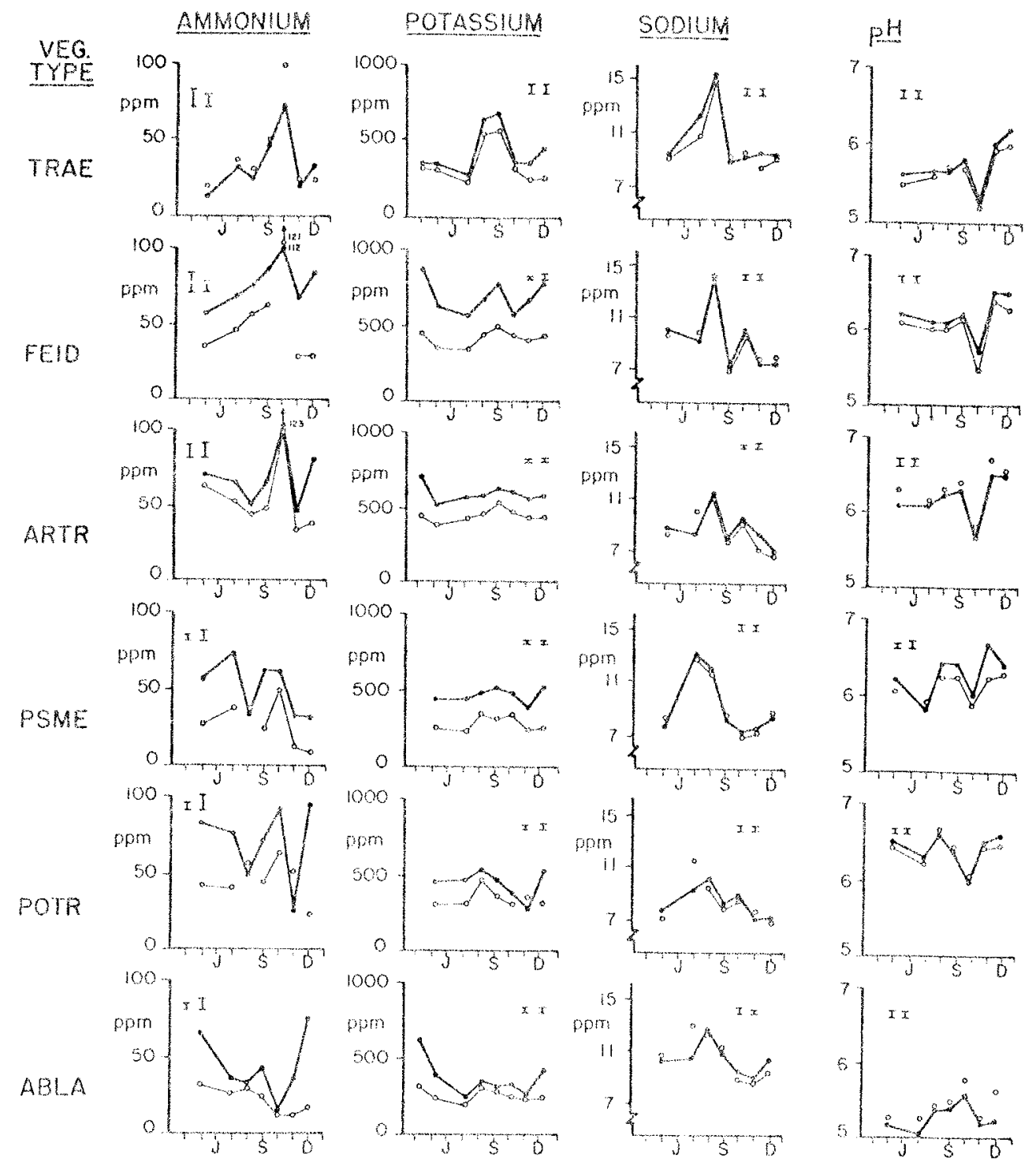

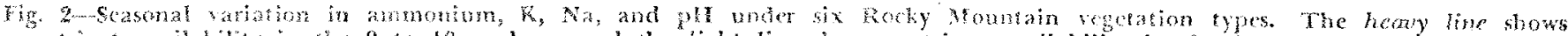

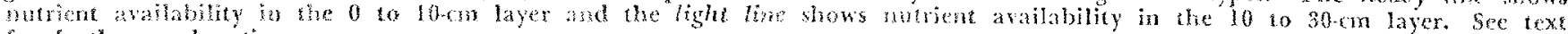
for furthex eaplanation.

Taylor, 1974; Gupta and Rorison, 1975). Stream water from deciduou forests of the eastem US carry large monnts of anmonium, nitrate, phosphate, potassium, alcum, magresium, and sodmon in the fall and spring (likens et al., 1977); this is due in part to the seasonal palien of water dischage, but it may also be due to seasonal valation in the avalibility of nutricnts to leaching.

The size of a dutrion pool must depend on inputs to and wilhdrawals from is (e.g.s Cole et al., 1977; Reuss and Innis, 1977). One can syeculate (i) that $P$ and a dilability rise in the swing bocause rapidly growing decomposer populations release induents more rapidy than they are absobed by ratively inactire plants; (ii) that $N$ and $P$ aralablity fall in the summer becase phants growing lomathmically absorb nurens laster than decomposers release then; (ii) that the autumn rise in avilability is due to high racrobial active after autum rains, the contribution of new substrates by senescing plants, and with relalively low plant activity; and (iv) that the decline in avilability of late anmm is ave to lowered mioro bial activity coupled with continued slow uptake by plants. The ple drops in the fall when $N$ and $P$ become more avalable; this may be due to release of $\mathrm{CO}_{2}$ by decomposers. The reason for earlier fall poaks in sodium (Angust) and $K$ (Seplomber) is less clear; perbaps materials are leached from aring plants in that osder (Thkey, 1971) or perhaps they are being released from microoganisins in the declining microbe populations (Blakemore, 1965).

Seasonal trends in mutrient avalability under Festa. ca, Arcmisia, Pscudotsugn, and Populus vegetation below $1,900 \mathrm{~m}$ were suikingly similar and notably ditferou from those olserved in an Abies stand near 2,000 m. There was less ariation across season in the Abies sand; spring and fall peaks disappeared except for solinm) and a weak midwinter peak in ammonium, nivate, potassum, alciom, and magnesium appeared. One might atribute the difrerences to a greater stability of the soll emvironment in the Abies forest; (i) due to its constant whiter snow cover, soll temperatures at $10-20 \mathrm{~cm}$ probably stay noa $0 . \mathrm{C}$ from November thromgh May (and ise to $5.10^{\circ} \mathrm{C}$ in Angust) while 
soils in lower stands with discontinuous snow cover are more thoroughly froten; and (ii) periods of soil water suess are significantly shorter (or nonexistent) an the Abids stand than in lower Fesiuca, Aricmisia, and Psudotsuga stands (Weaver, 1977). The tendency of ammonium, nitrate, ralcium, and magnesium to be most avaluble at midwinter may be due to constant slow microbial activity coupled with litte uptake by trese exposed to harsh above-snow conditions.

Inspection of Fig. 1 and 2 suggests that if no sampled natural vegetation in January-March he would measure minimum nutrient avalabilities, if he sam. pled in May-July he would meaure normal growing senson levels and if he sampled in September-October he would find maximum nutrient avalabilities. As * standard sampling period the winter or spring may be better than the fall because avalability is changing less rapidly. Since availability may vary little in stands with deep snow cover, the season of sam. ping is less mportat in such stands.

\section{Variation "n Nutrient Avaiability Between Vears}

Nitrate, phosphorus, and potassium were studied in both 1974 and 1975; all three were less available in the second year. The striking drop in the availability of these mutriens in the wheatfield was undoubtedy due 10 plant uplake: as noted above, the field as essentially plant-free in 1974 and was vege. tated in 1975. Severe drops observed in okher vegetation types may have been due to differences in weather noted abova: the spring of 1974 was warm and dry while the spring of 1975 was cool and nomally moist.

\section{Average Wurient Avalabiluy in Six Varously Voguctaced Siands}

Since the quantitics of nutrients arablable in soils vary beween regetation types (Cutis, 1959; Daubenmire, 1968; and Weaver, 1979), quantities of nutrients avalable (average of seven mexsurcments made be tween May and December of 1974 ) in the $10 \mathrm{p} 10 \mathrm{~cm}$ of the solls we studied are expected to vary between stands. Average nitrate-N under conifer forests ranged from 2.6 to 2.9 ppm while under other vegetation types it ranged from 3.039 phan. Ammonium nitrogen was atso less avalable under conifer forests (10-49 ppm) than under other natural vegetation $(70.78 \mathrm{ppm}$ ). Bray phosphorus may be more avalable under fores than grass shobland types. Potassim avalability de ched up the water gadient from a Fostuca grassland (674 ppon) to an Abics forest (937 ppm). Calciun avil ibility aclined similarly up the water gradient from sostuca grastand (21 ppm) to an Abies forest (11 phin) except in Populus groves $(23 \mathrm{ppm})$. Magnesium andabilicy was loss under Aremish shrubland and Prondotsuga forest (2.629 meq/100 g) than wader other vegtation iypes $(3.4 .4 .8 \mathrm{meq} / 100 \mathrm{~g})$. Sodium conten is about $0.4 \mathrm{med} / 100 \mathrm{~g}$ thomghow the water gradient. The pII was 5.3 in the Abies forest and 6.2 and 6.4 maler other vegetation tyjes. Organic matter contents lay in the $5.65 .7 \%$ range in all stands. Trends in nutrient avilability between vegetation types show in the 0. 10 $10 \mathrm{~cm}$ bol layer werepered in the 10. to $30-\mathrm{cm}$ horizon.

A comparicon of the 0.1010 and 10 to $30 \mathrm{~cm}$ hor uns (rig. 1) shows bhat orgatic matler is Jess concen trated in the lower layer, that pHs are similar or slightly lower in the lower horizon, that nutrient elements $(N, P, K, C a$, and $M g)$ are less available in the lower horizon except for $\mathrm{P}$ and $\mathrm{Mg}$ in the Abies stand where they are similar, and that sodium concentrations do not differ between the horizons.

The soil of the wheat field studied differed from that of the adjacent grassiand in two ways. First, the dif ference between the 0 - to 10 - and 10 . to $30-\mathrm{cm}$ horizons is less in the ficld than in the grassland; this is probably due to mixing of the layers by plowing and/or erosion of the richest topsoil. Second, the ammonium (62-37 ppm), potassium (509.380 ppra), magnesium $(4.7-3.9 \mathrm{meq} / 100 \mathrm{~g})$, calcium $(19.6-13.9 \mathrm{meq} / 100 \mathrm{~g})$ and organic matter $(6.9 .5 .0 \%)$ contents of the iop 30 cm have all been reduced significantly (about 20\%) by 75 years of laming. The $\mathrm{pH}$ is lower on the farmed (5.7) than on the unfarmed (6.1) hand. Nitrate, phos. phorus, and sodium are apparently more available on fromed than unfarmed land, perhaps due to fertilizer application. Similar changes have been observed in Ohio, Oklahoma, lowa, Texas, and Colorado (Schollenberger, 1920; Garman, 1948; Thompson et al., 1954 ).

\section{AKNOWLEDGNENTS}

We are gratefit for soll andjes provided by the MSU Soil resting Jab. Solls were identificd by L. Munn of the MSU Plant and Soil Scione Deparment.

\section{LITERATURE CITED}

1. Anderson, $T$, and $A$. Tiedemann. 1970. periodic viation in physical and chemical properties of two central Vashingion soils. USDA Forest Service, Forest and Range Experiment Station Research Note PNW 125. Corrallis, Oregon.

2. Ball, $\mathrm{D}$, and $W$. Willians. 1968 . Variability of soil chemical propertics in 1 wo unculivated brown carths. J. Soil sci. $19 \cdot 379-391$

3. Blatume, M. 1966. Scasonal changes in the amounts of phosphoms and potassium dissolved from soils by dilne alcium chloride solutions. J. Agric. Sci. Camb. 66:139-146.

4. Preminer, f. 1065. Inotranie forms of nitrogen. 1191-1198. In C. Black a al. (co.) Aluthots of soil analysis, Pare 2 Agonomy 111911-1198. Amer. Soc of Agromomy, Madison. Wis.

5. Cole, y. G. Innis, and J. Stewat. 1977. Simulation of phosphome geting in semarit grassiands. Ecology 58:1-15.

6. Curtis, I. 1559. The regctalion of Wisconsin Univ of Wisconsin Press, Madison.

7. Darey, A., and $K$. Taylor. 1974. Scasmal pattems of nierogen arablabity in contrating sols in the Chillem Hills. f. Eol. 62:799-807.

8. Daubcmise, R. 1970. Seppe regetation of Washington. Wash Agric Exp. Str. Tect Bull. 62, Pullman.

9. Dabommire, $R_{\text {, and }}$. Daubenmire 1968. Forest regeta. tion of castern wahingon and northern daho. Wash. Arric. Exp. Sin. Bull. 60 , Pullinan.

10. Garbouches, 1. 1966. Changes occurring during a year in the soluble phosphomens and potassium in sril under crops

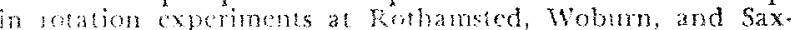
muntham. Y. Sujc Sci. Canb. 65:399-412.

11. Gaman, 19. 1018. Organic phosphoms in oklahoma soils. Okla. Sad Sci Proc. $28: 50100$.

12. Guma, and I. Romism. 1975. Sxasonal differcues in the astibuilty of morients down a potzolic profile. I. Ecol. $63: 021-534$.

13. Hitcheock, and 1. Comunist 197\%. Flora of the Pacific Numbest. Inive of Thashington Tress, Scattle.

14. Likeis, G., H. Bomann. R. Pjerec, J, Eaton, and N. Johnson. 1977. Blogeolumistry of a forested reosystem. Springer Verlag, Yew Fork.

15. Mueggler, W., and W. Mandl. 1974. Momban gassand and shobland habiat lypes of western Montana. LSOA 
Forest Sevice, Intermin. Fovest \& Range Exp. Stn. Int Report, Oggten, Dtah.

16. Olsen, 5., and L Dean. 1965. Thosphorus. In C. Black ef al. (ed.) Methods of soil analysis, Bart 2. Agronomy $9: 3035$ 10,9. Aner. Sor of Agronomy, Madison, Wis.

17. Plister, R., B. Kovalchik, S. Amo, and R. Presby. 1977. Forest habiat types of Montana. Intcrmtn. Forest a Range Exp. Stn. General Toch. Rep: INT 34. USDA Forest Service, Oggen, Uhah

18. Retse, $y$, and $G$. Innis. 1977. A grassiand nitrogen flow simulation model. Ecology 58:379-388.

19. Russell, E. 1961. Soll conditions and plant growth. John Wiley 8 Sons, New York.

20. Sonollenberger, C. 1920. Organic phosplorus content of Ohio soils. Soil Sci. 10:127-1 1 1.

21. Sims, $J$ and V. Yaby. 1970 . Smplified colorimetric te. termination of soll organic matrer. Soil Sci. 112:197-14l.

22. Smith, $x, B$. Ellis, and J. Grava. 1957 . Ost ar acid flonide solutions for extraction of phosphorus in alcarous sonis wo which rock phosphate has ben arted. Soil Sci. Soc. Amer. Proc. 31:400404.
29. Snell, $r$, and $C$. Snell. 1950. Colormetric methods of analyis 2 na ed Vol 1 D Van Nostrand Co. New York.

24. Soll Survey Staff. 1975. Soil taxonomy. USDA Agricultural Yandbook 496. U.S. Govt. Printing orfice, Washington, D.C

25. Thompson, L. C. Black, and J. Tocllner, 1954. Occurrence and minemalization of orianic phosphorus in solls, with par. cicular reference to ssociation with nitogen, carbon, and pH. Soil Sci. 77:185-196

26. Tukey, Yt 1971. Teaching of substances frosn plants. In Biochenical interactions among plants. Nat. Academy of Sci. Washington, D.C.

27. Weaver, $T$. 1977. Root distribution and soil water regiros in nine habitat ypes of the northern Rocky Mounains. p. 299-2s. In J. Marshall (ed.) The belowground ecosysem. Range Sci. Dept. Sci. Series no. 26. Colorarlo State Univer. sity, Font Collins.

28. Wover, $T$. 1979. Changes in soils along a vegetational faltidulinaly gradient of the nothern kocky Mountains. $p$ (no- ovo. in C. T. Youngberg (ed.) Proc. Sth North Amer. ican Forest Soils Conf. (August 1978 , Fe Collins, Colo. Oregon Salae Univ. Press, Corrallis, (in press).

\title{
Cation Release from Michigan Spodosols Leached with Aspen lea Rxtracts
}

\author{
Prul W. Adams and James R. Borle 2
}

\begin{abstract}
A 15 TPACT
Solt samples $(<2$ man) from the horitons of three sandy Wichigan Spodosols of rarying productivity were leached with water extracts of populus gramidentata Nichx. leaves. Labora. cory leaching expenments vere ned to simulate natural weather. ing of soil gimerals by hydrogen tons of organic achis and the complexing of cations by organic componds in the extarts. All of the son samples released significant amomts of $\mathrm{Mg}$ $\mathrm{Na}$, and $\mathrm{Fe}$, ant most released $\mathrm{Ca}$. Using data for Fe relcased by the feadings and toxing data for subonl fe accmulation and groum water losese in simblar soils, an estimate was made at the number of yoars of ficld conditions simulated by the laboratory areancuts. The anmal etenental release through mineral teahering in the $A$ horizon in each soil was then estimated. Although estimated Ca wahering mass sere inolbly low, estumated rates of $N$ a wathering were comparable to those observed for pedzol soils in New England.
\end{abstract}

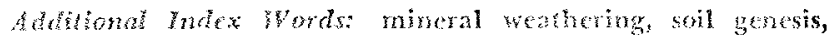

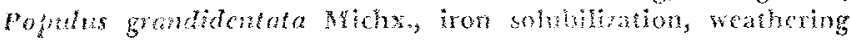
rates.

Adams, P. W., and J. R. Boyle 1979. Cation relcase from M. chigan Spodomoli loached with aspen kaf extacts. Soil sci. Soc. Am. J. Am. J. 43:593-506.

Amovar mineral weathering and soilfoming D. processes have been studie extonsively in the hboratory, the evaluation of, or extrapolation of laboxatory data to weathering on the ecosystem sale has been less frequently attempted. Analyses of dianage water composition have been ued to chimate at al weathering rates (1), 19), but this nothod is not applicable to many sites and requires careful experimental design to obtain reliable resulis $(12,17)$. Mincralogical and chemical analyses have also been used to

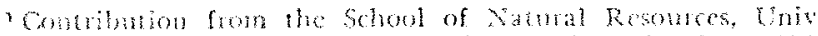
of Michyon. Am Arbor, th 40100 Recived 23 Oct 1978 Approver at Ja, 1979

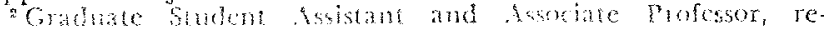
perticly. evaluate soil mineral weathering when the profile of interest indudes relatively unaliced parent material (2). This method can provide useful information on total profile changes due to weahering and soil development, but estimites of rates of mineral weathering obtained from this information are less reliable.

This paper outlines some laboratory experiments designed to simulate several years of field weahering in some Michigan forest soil samples in order to estimate curent rates of cation release through weathering in these soils. Natual organic materials were employed as weathering agonts since it is likdy that such materials play a primary wole in the genesis of 5 podosols. The solubiliation of mineral Fe by aqueous extracts of fresh and decomposing tree leaves has been demonstrated $(3,7,16)$ and contrasted with low Fe solubilization by $\mathrm{H}_{2} \mathrm{O}$ and $\mathrm{CO}_{2}$ charged $\mathrm{H}_{2} \mathrm{O}$ (23). Iron and other clements have been solubilized through laboratory mineral weathering with organic acids (A, $3,23)$ and the significance of cation chelation in such reactions has been suggested $(4,23)$.

\section{METHODS}

Soil samples used for the wathering experiments were col. icced from thee forested sifes at the Vniversity of Michigan Biologial station bear pellson in northern lower Michigan. This area recoves a culy average of $79.4 \mathrm{~cm}$ of precipitation 3nd the mon ammal temperature is $5.5^{\circ} \mathrm{C}(8,21)$, The sites are dominated by Populus. Queves and Acer species and were daciffed carlier as yosd, intermediate and poor in relative aspen pudation (20).

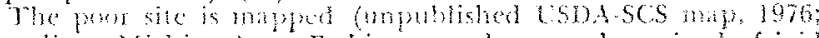

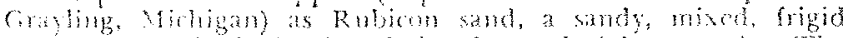

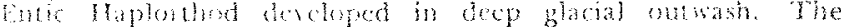

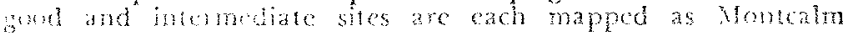
framy sand, a sandy, mixed, frigid Affic Haplorthod. The upper botions of this soll were formedit in sandy outwash material with an underlying horizon scumb of simbar of finer textures dechered during an caller pelologic period.

Samples fiom the a horion were collected from the plots rambonly focater orer a 0.5 ha area at cach of the sturly sites The buth samples were compented, air thed, and soll material pasing thomgh a $2 \mathrm{~mm}$ seve was ned in the wathering ex. periments. Panticle size distributions of the omposites are 